\title{
KUFR DALAM PERSPEKTIF HADIS
}

\section{Zainal Abidin}

STAIN Datokarama Palu, Jl. Diponegoro 23 Palu

e-mail: abidzainalabidin@gmail.com

\section{Abstract}

Kufr is often considered an antithesis of imân. In the mean time, imân is the fundamental part of Islamic teaching. Nevertheless, as far as the sources of Islamic teaching are concerned, the term $k u f r$ cannot necessarily be grasped as disbelief in Allah (God). In some hadiths (the prophet's traditions), we find some terms of kufr that do not indicate disbelief in Allâh at all. Even, some merely indicate disobedience of the Muslims in performing their Islamic teachings, such as performing salât. Based on this, this article deals with kufr from the hadith perspective.

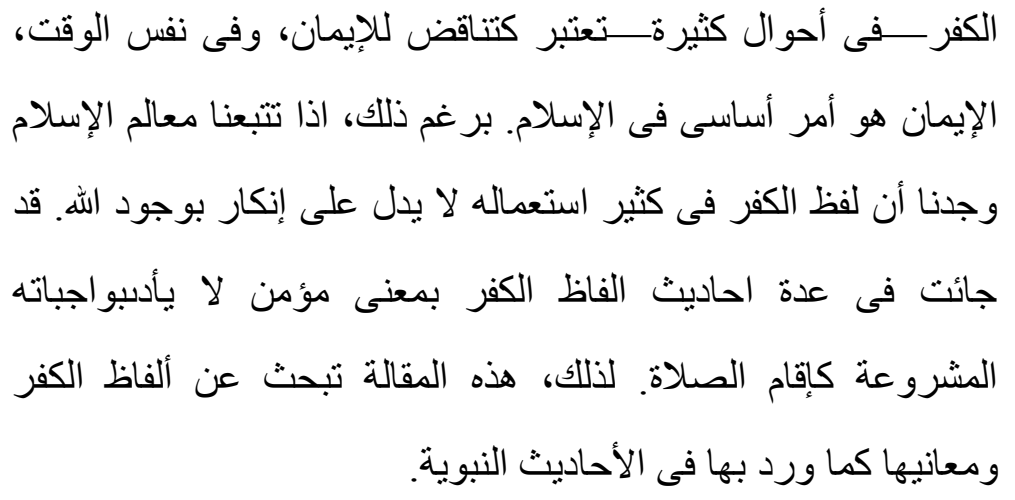

Kata Kunci : $k u f r$, perspektif hadis, dosa besar 


\section{PENDAHULUAN}

Kufr pada intinya merupakan antitesis dari iman, sedangkan iman adalah bagian dari ajaran atau aspek Islam yang paling pokok dan fundamental.

Pada umumnya, penulis Muslim membagi ajaran atau aspek Islam kepada tiga hal, yaitu akidah, syariah dan akhlak (Syaltut, t.th. :11). Pengelompokan ajaran atau aspek Islam yang terbatas pada tiga bidang di atas sudah mulai ditinggalkan oleh penulis-penulis di era modern. Nasution (1979), misalnya, merinci Islam ke dalam aspek teologi, ibadah, moral (akhlak), mistisisme, filsafat, hukum, sejarah, kebudayaan, pembaharuan dalam Islam, dan politik.

Menurut hemat penulis, pembagian aspek atau ajaran Islam oleh Nasution lebih realistis dan lebih dapat menggambarkan Islam secara utuh dan komprehensif, bahkan aspek-aspek itu sendiri dapat lebih berkembang sesuai dengan kemajuan zaman, di mana Islam turut mengambil bagian dalam perkembangan itu (Rahman, 1979:15).

Dalam sejarah perkembangan pemikiran Islam, kufr adalah satu pokok masalah yang pertama diperbincangkan oleh aliran kalam (teologi Islam). Kekacauan politik akibat terbunuhnya Usman bin Affan pada tahun $35 \mathrm{H}$. berlanjut sampai zaman Ali bin Abi Thalib. Kekacauan ini mencapai klimaksnya dengan meletusnya perang Jamal pada tahun 35 H./656 M. yang disusul dengan perang Siffin pada tahun $36 \mathrm{H}$. $/ 657 \mathrm{M}$.

Peperangan di atas - dilihat dari sudut politik - merupakan titik tolok munculnya aliran kalam dalam Islam, khususnya perang Siffin yang justru menjadi penyebab lahirnya golongan Khawarij, yaitu golongan yang pertama kali mencetuskan masalah-masalah teologi dalam Islam yang selanjutnya dalam perkembangan penalarannya melahirkan ilmu kalam (Cawidu, 1991:9).

Khawarij tampil dengan pendapat-pendapat yang kontroversial, khususnya dalam hal pengkafiran terhadap orang-orang yang melakukan dosa besar. Eksistensi dosa besar ditetapkan secara eksplisit dengan term kabâir al-ithm (Q.S Al-Shuarâ' (42):27; Q.S Al-Najm (53):32). Akan tetapi, Alquran tidak merinci perbuatan apa saja yang termasuk dosa besar sehingga perlu dilakukan kajian tentang $k u f r$ dalam perspektif hadis. Kajian ini perlu dilakukan agar diketahui bagaimana konsep kufr menurut hadis. 


\section{KLASIFIKASI HADIS-HADIS TENTANG KUFR}

Berdasarkan hasil takhrîj al-hadîth yang telah dilakukan, ditemukan kurang lebih 400 hadis yang berbicara tentang $k u f r$ atau diduga memiliki arti yang sama dengan kufr. Hadis tersebut ditemukan dalam seluruh kitab (al-Kutub al-Sittah).

Term Kufr disebut dalam Alquran sebanyak 525 kali, dan mempunyai arti yang bervariasi, bukan $k u f r$ dalam penegrtian tidak bertuhan, musyrik, murtad, atau tidak menganut agama Islam ('Abd al-Bâqî, 1981:605-613).

Sebelum dilakukan klasifikasi hadis tentang $k u f r$, terlebih dahulu diungkapkan asal-usul kata kufr tersebut. Kufr terdiri dari huruf kaf, $\mathrm{fa}^{\prime}$, $\mathrm{ra}$ yang menunjuk satu arti yaitu menutup atau menutupi. (Zakarya, 1994:931). Sedangkan dari segi istilah, kufr yang dianggap antipode dari iman, adalah kufr dalam arti tidak bertuhan (ateis), musyrik, murtad, atau tidak menganut agama Islam (Cawidu,1991 :8).

Hadis yang berbicara tentang $k u f r$ banyak sekali sehingga perlu dilakukan klasifikasi agar diketahui makna kufr yang dikandung oleh hadis-hadis tersebut. Adapun klasifikasi hadis-hadis yang terkait dengan kata yang dijadikan objek kajian di sini ada tiga subtema yaitu (1) tentang meninggalkan salat; (2) melupakan nikmat; dan (3) membunuh sesama muslim.

- Susunan sanad dan matan hadis tentang meninggalkan salat

- Riwayat Muslim

166

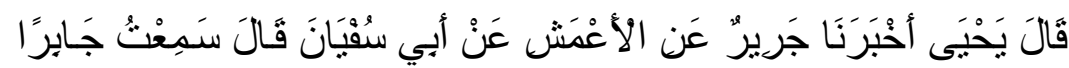

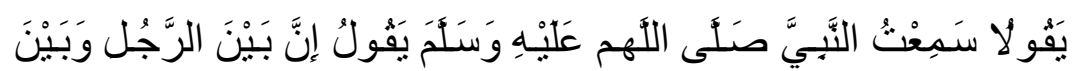

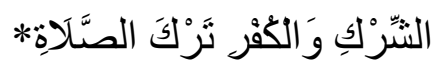

- Riwayat al-Turmuzî

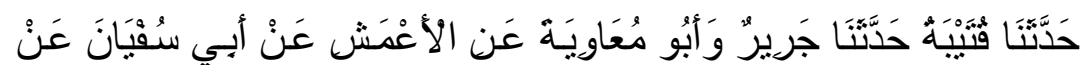

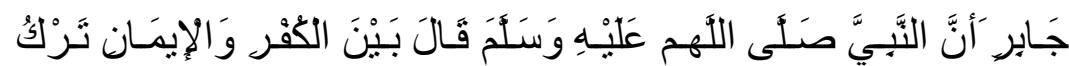

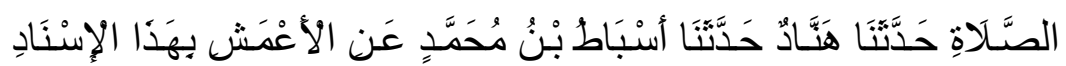

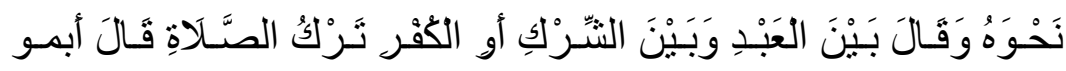

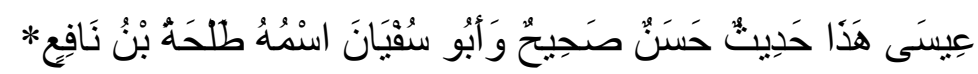




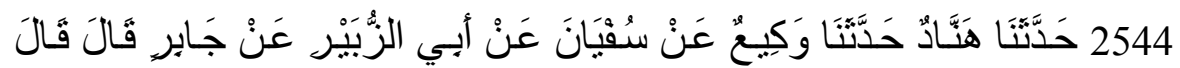

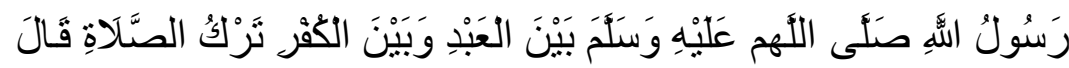

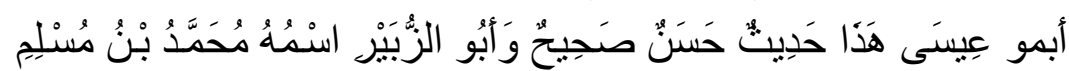

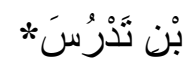

- Riwayat Abû Dâwud

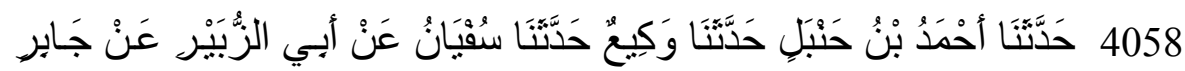

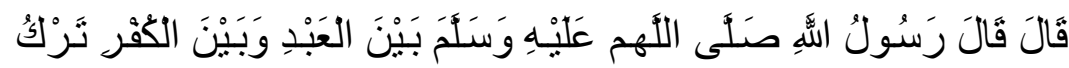

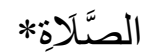

- Riwayat Ibn Mâjah

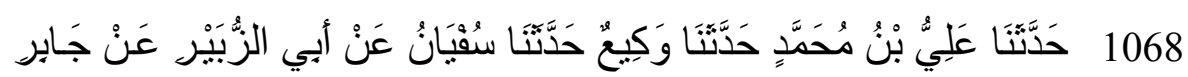

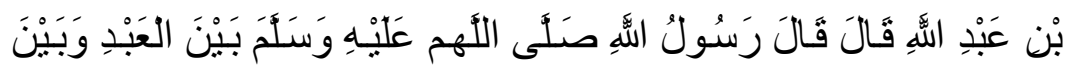

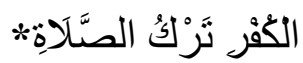

- Riwayat Ahmad bin Hanbal

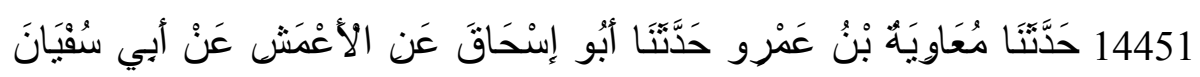

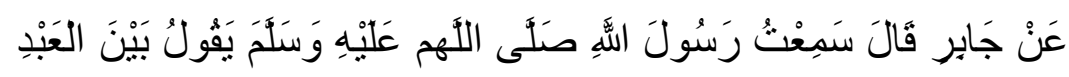

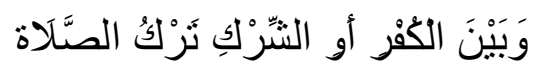

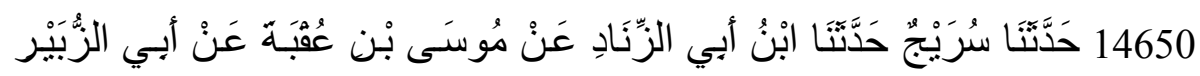

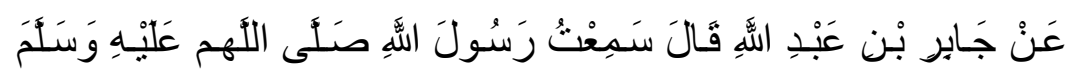

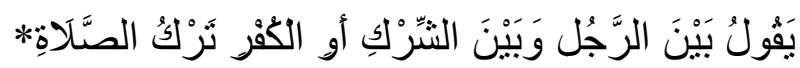

- Riwayat al-Dârimî

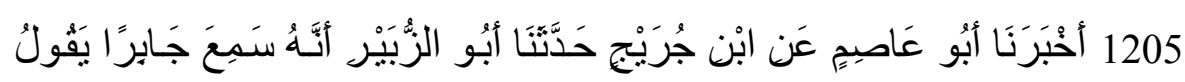

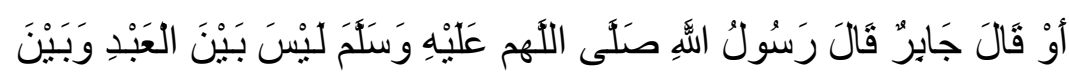




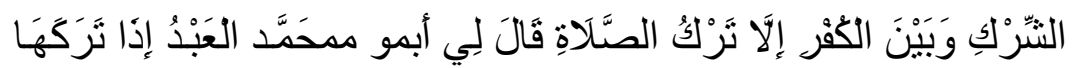

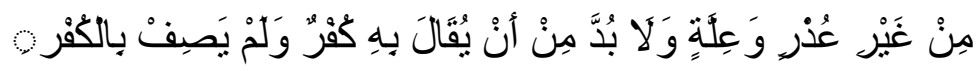

- Susunan sanad dan matan hadis tentang melupakan nikmati. - Hadis Ahmad bin Hanbal

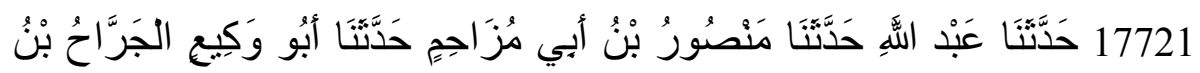

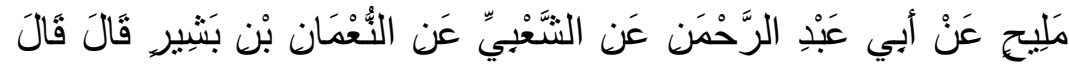

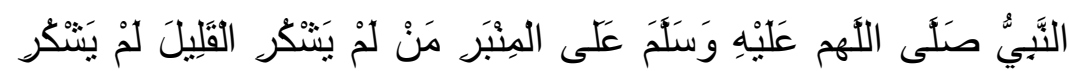

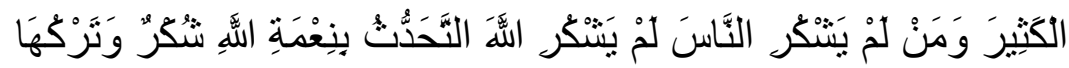

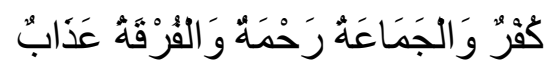

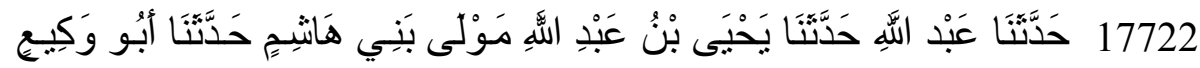

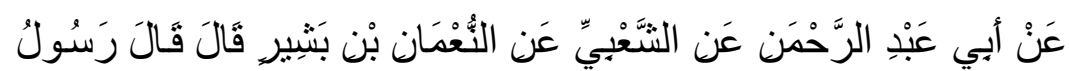

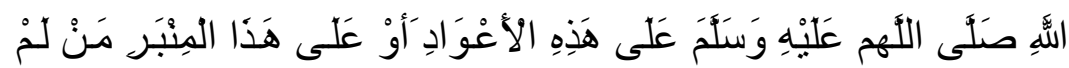

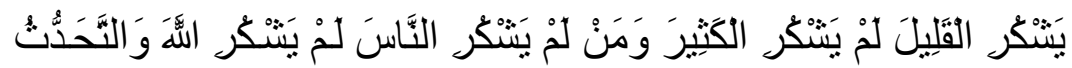

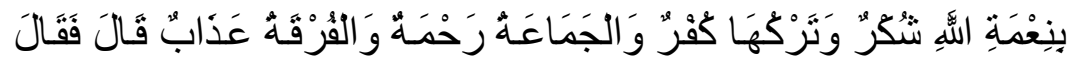

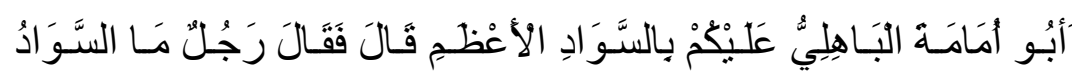

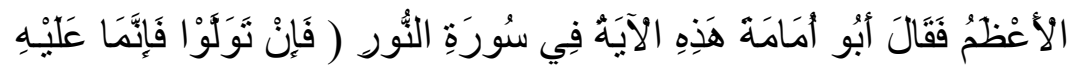

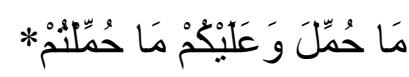

- Susunan sanad dan matan hadis tentang membunuh sesama muslim.

- Riwayat Bukhârî

30

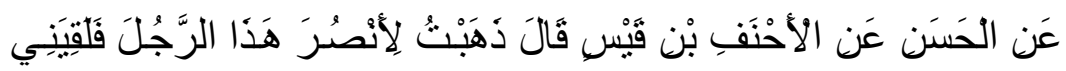

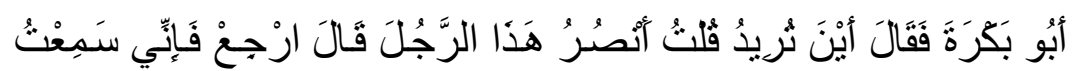




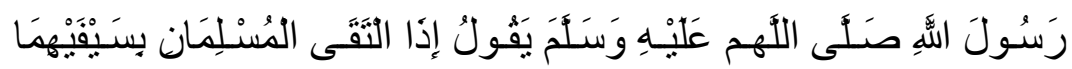

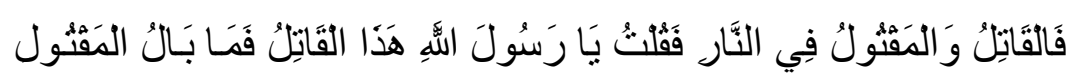

- Riwayat Muslim

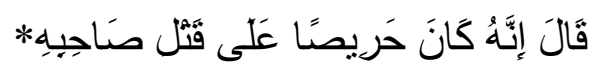

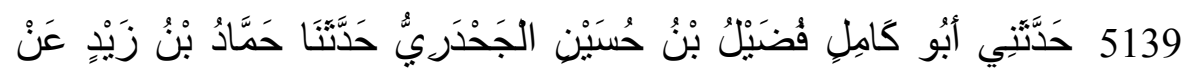

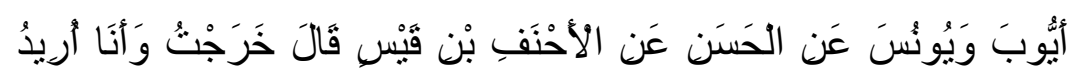

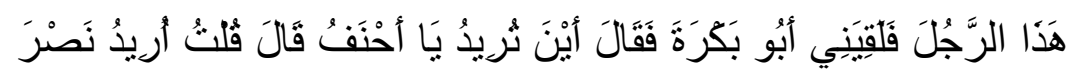

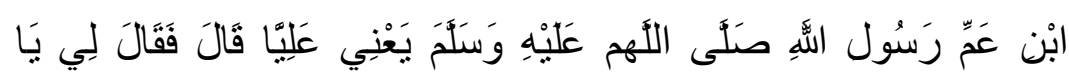

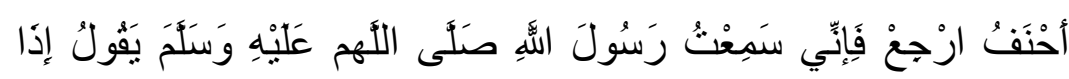

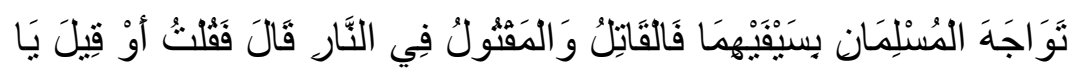

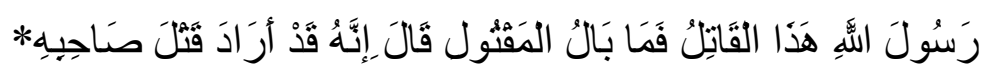
5140

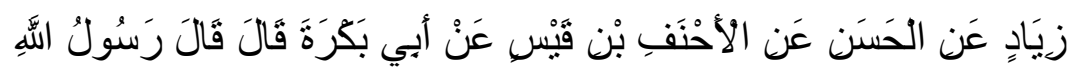

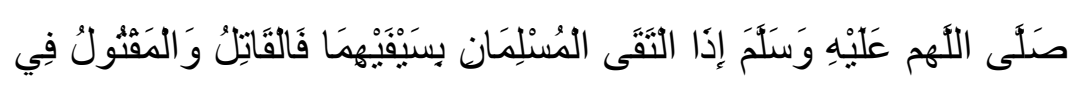

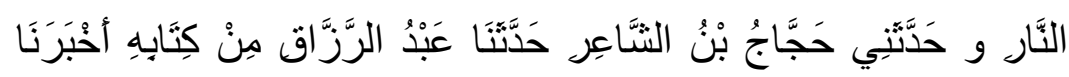

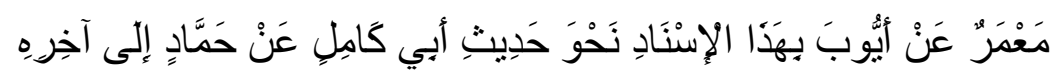

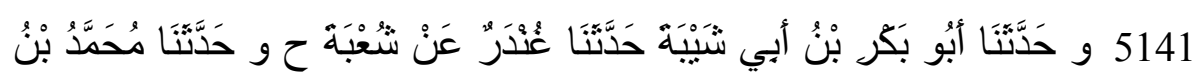

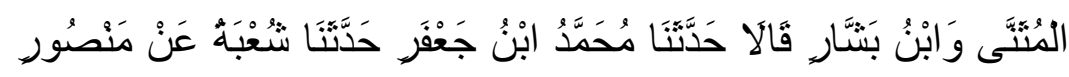

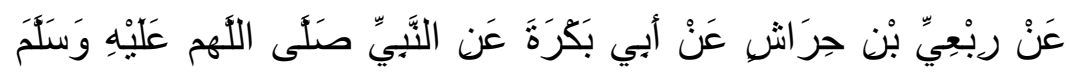

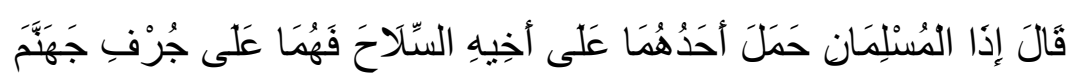

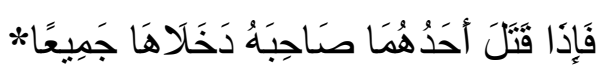


- Riwayat al-Nasâ'î

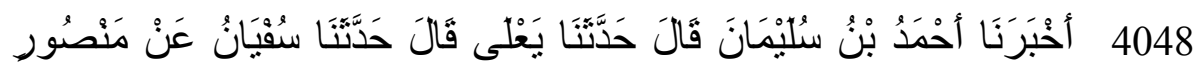

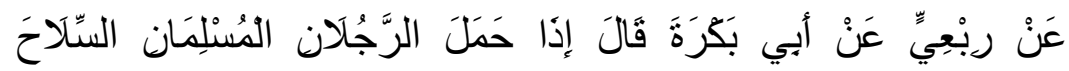

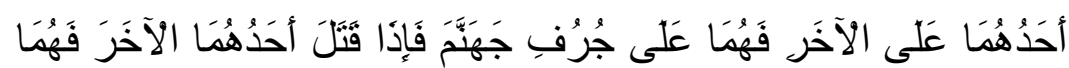
فِي النَّار

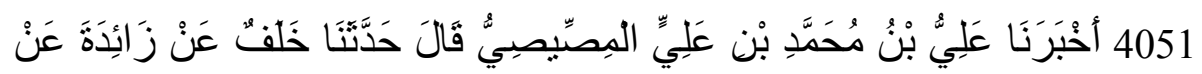

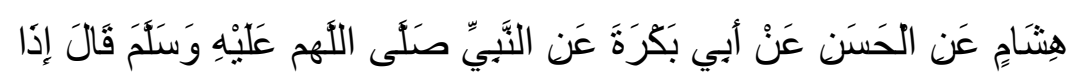

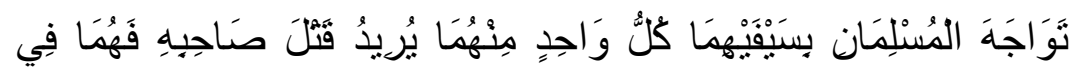

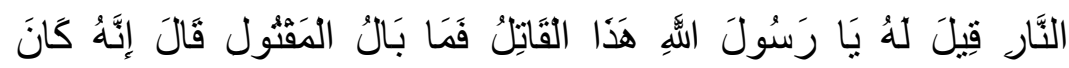

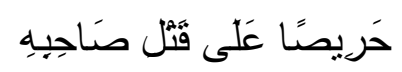

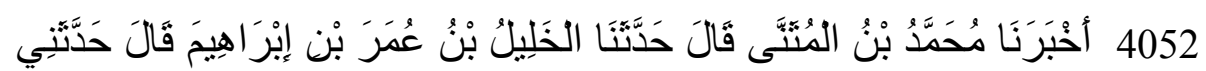

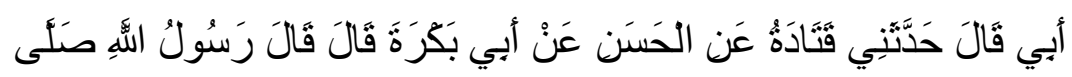

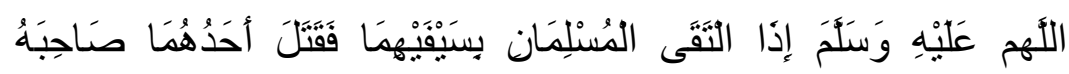

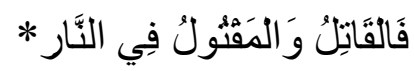

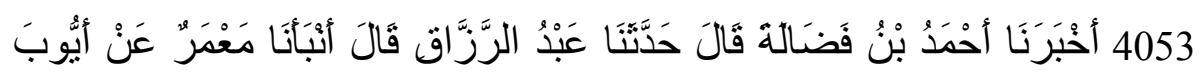

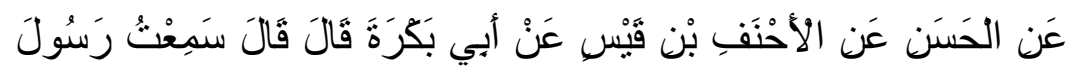

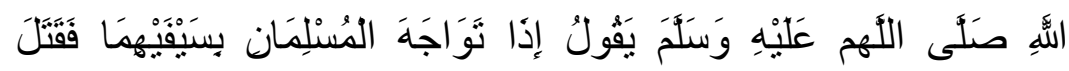

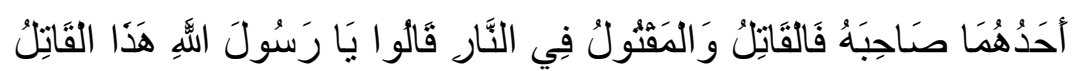

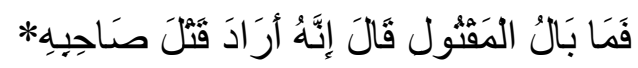

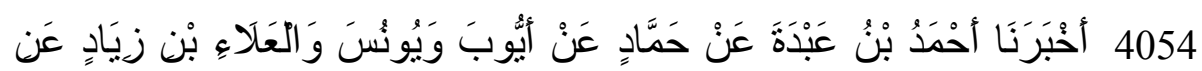

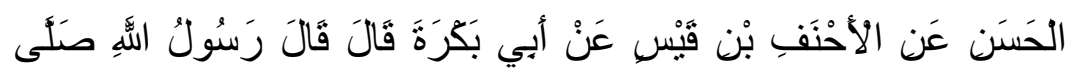


Jurnal Hunafa Vol. 5 No. 1, April 2008:87-100

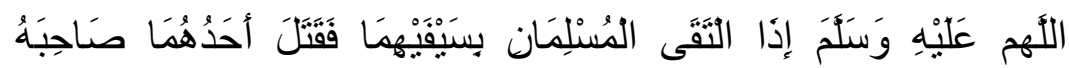

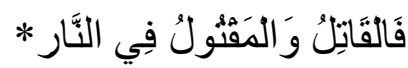

- Riwayat Ibn Mâjah

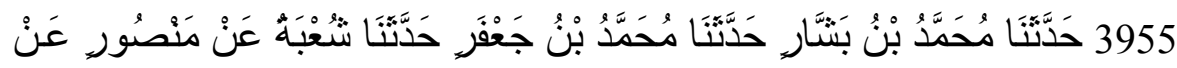

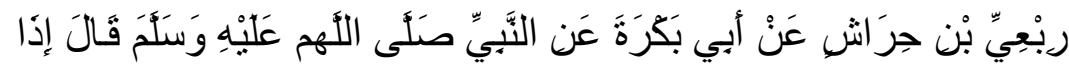

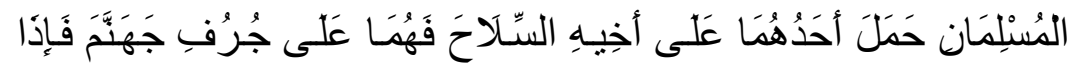

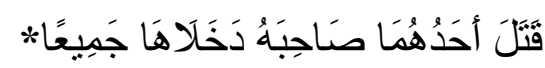

- Riwayat Ah $\square \square \operatorname{mad}$

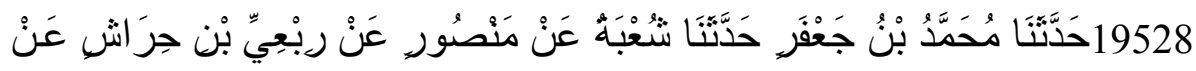

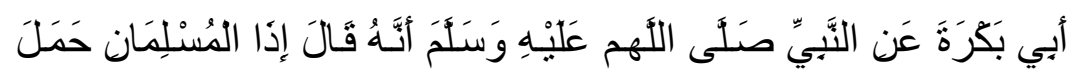

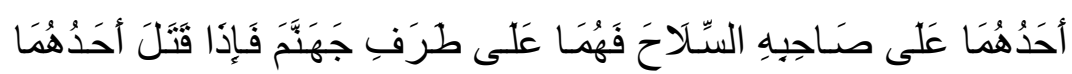
صَاحِبَهُ دَخَلاهَا جَمِيعًا

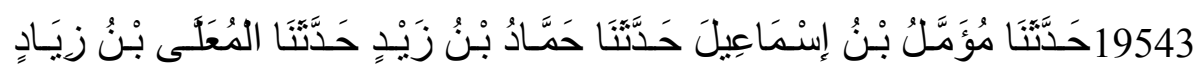

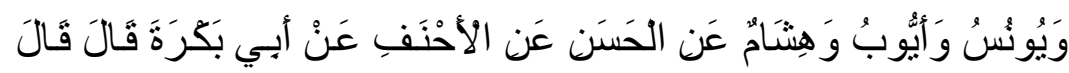

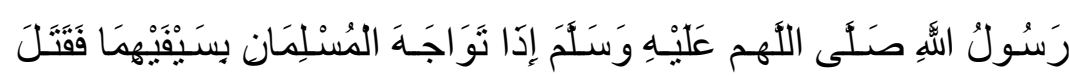

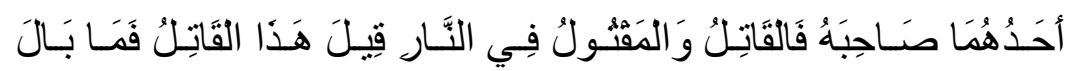

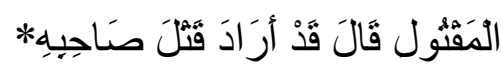

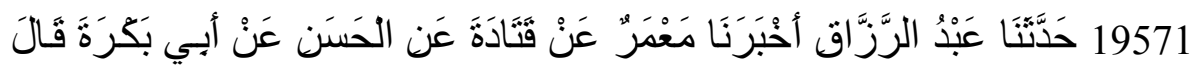

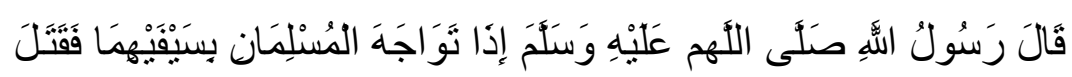

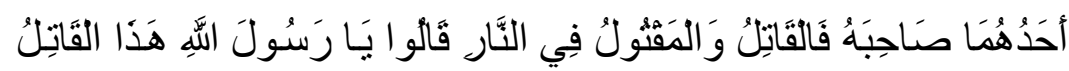

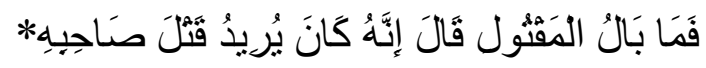




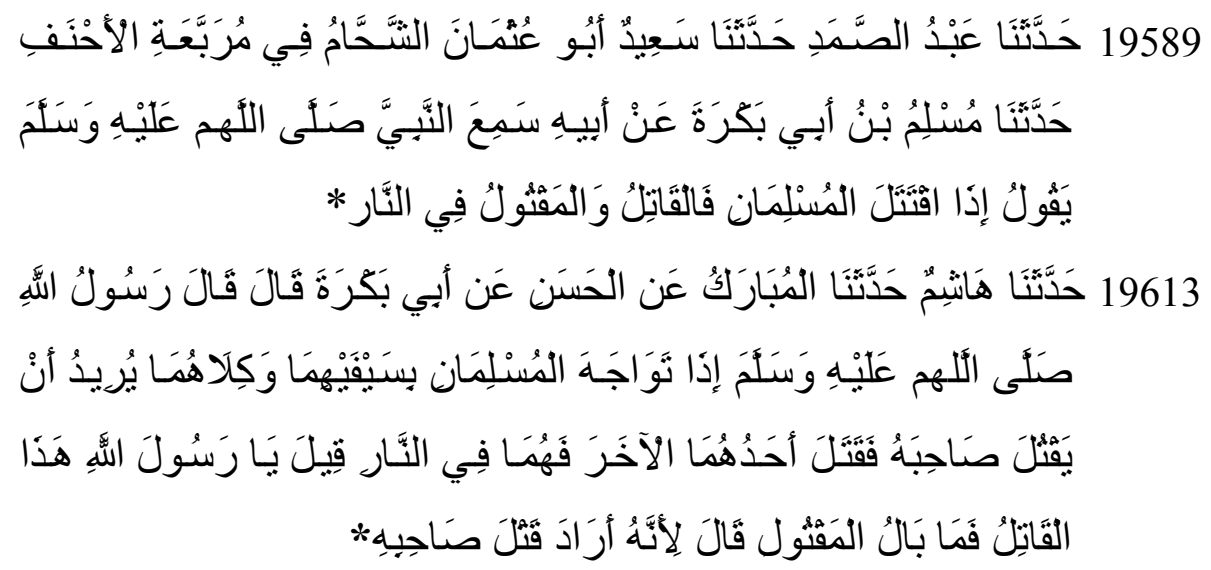

\section{ANALISIS}

Secara naluriah, setiap orang beragama sangat tidak senang dijuluki kafir, bahkan tidak jarang di antara mereka ada yang rela mempertaruhkan jiwanya untuk menolong atau membela diri dari tuduhan kafir. Hal ini menunjukkan bahwa masalah $k u f r$ adalah masalah yang sangatt peka bagi manusia, baik sebagai individu maupun sebagai kelompok. Akan tetapi, justru karena kepekaannya itulah, masalah kufr tetap aktual dibicarakan, terutama di kalangan pemikir Muslim (Cawidu, 1991:9).

Hadis nabi, menurut petunjuk Alquran, merupakan sumber ajaran Islam yang kedua setelah Alquran. Itu berarti bahwa untuk mengetahui ajaran Islam yang benar, selain diperlukan petunjuk Alquran, juga diperlukan petunjuk hadis nabi (Amin, 2004:3). Oleh karena itu, hadis-hadis mengenai kufr akan dianalisis secara tekstual, intertekstual, dan kontekstual sehingga diperoleh maksud yang dikandung oleh kufr itu sendiri.

\section{Akibat Meninggalkan Salat}

Dalam matan hadis (sebagaimana dikutip sebelumnya) diriwayatkan bahwa nabi saw. bersabda:

$$
\text { ان بين الرجل و بين الثرك والكفر ترك الصلاة }
$$

Terjemahnya:

Sesungguhnya yang membedakan seorang muslim dengan musyrik dan kafir adalah orang yang meninggalkan salat 
Term kufr yang terdapat dalam matan hadis di atas, jika dipahami secara tekstual, maka orang muslim yang meninggalkan salat dengan sengaja atau tanpa uzur, maka posisinya sama dengan musyrik dan kafir karena dianggap telah melakukan dosa besar.

Secara intertekstual, hadis tentang meninggalkan salat tidak memiliki tarawwu' atau keragaman makna, bahkan lafal-lafal hadis hampir tidak ada perbedaan yang menyebabkan perbedaan makna seperti الرجل dan العبد.

Sementara secara kontekstual, makna kafir dan musyrik tidak dapat dipahami sebagai orang yang murtad atau mensekutukan Tuhan, karena memang term kufr tidak mesti selalu berkonotasi pengingkaran atau pendustaan terhadap Tuhan, rasul-rasul-Nya atau ajaran-ajaran mereka, melainkan dapat dipahami sebagai kufr dalam pengertian yang lain, yaitu dosa besar atau sangat tidak terpuji, kalau mau dipahami dengan kufr (murtad), maka yang dimaksud dengan meninggalkan salat, yaitu bukan sekedar tidak mengerjakan salat (walau ada kesempatan, tidak ada uzur, dll.), tetapi tidak percaya terhadap ajaran salat itu sendiri. Bahkan hadis riwayat Al-Darimî secara tegas mengatakan bahwa orang yang meninggalkan salat secara sengaja (hatinya iman) maka tidak boleh disebut kufr karena belum ada sifat-sifat kekufuran pada dirinya. Bahkan tercermin dalam hadis nabi yang melarang seorang muslim mengkafirkan atau memanggil dengan sebutan "kafir" kepada sesama Muslim (Cawidu, 1991:9).

Bila dikaitkan dengan Alquran, menurut hemat penulis, tidak ada satu ayat pun yang dapat dipahami atau diduga bahwa orang yang meninggalkan salat itu dikategorikan atau masuk dalam pengertian $k u f r$ (murtad).

\section{Akibat Melupakan Nikmat} bersabda:

Dalam matan hadis (sebagaimana dikutip sebelumnya) nabi

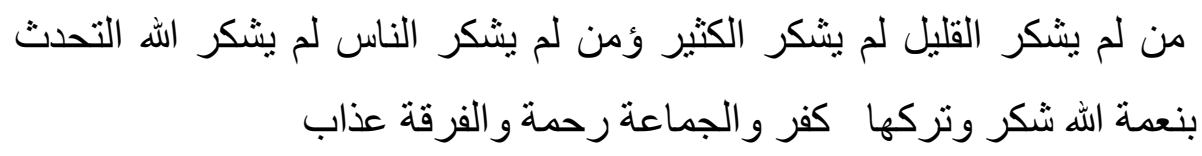


Terjemahnya:

Barang siapa yang tidak mensyukuri yang sedikit, maka ia belum (pula) mensyukuri yang banyak, barang siapa yang tidak berterima kasih kepada manusia, maka belum berterima kasih kepada Allah, menyebut-nyebut nikmat Allah adalah bagian dari syukur, dan tidak menyebut-nyebut nikmat Allah adalah kufr (ingkar).

Kata kufr dalam hadis di atas tidak dapat dipahami secara tekstual, tetapi secara kontekstual, yaitu orang yang tidak mensyukuri nikmat Allah dikategorikan sebagai kafir dalam pengertian melupakan tnikmat itu.

Pada dasarnya, syukur bermakna "menampakkan nikmat" sedangkan kufr sebagai kebalikan dari syukur yang berarti melupakan atau menyembunyikan nikmat. Nikmat dari Tuhan pada hakikatnya adalah segala yang maujûd di dunia ini sebab semuanya mempunyai kegunaan dan dapat mendatangkan kebaikan bagi manusia, baik langsung maupun tidak langsung (Al-Asfahânî, :265).

Karena syukur adalah lawan dari kufr (salah satu pengertiannya), pengertian kufr nikmat diformulasikan sebagai penyalahgunaan nikmat yang diperoleh, penempatannya bukan pada tempatnya dan penggunaannya bukan pada hal yang dikehendaki dan diridai oleh Allah sebagai pemberi nikmat (Q.S Ibrâhim (14):7,34); Q.S Al-Baqarah (2) :152).

Dari uraian-uraian tersebut dapat dipahami bahwa pengertian $k u f r$ dalam hadis tidak semata-mata berarti kufr karena tidak beriman kepada Allah, tetapi memiliki makna yang lebih luas. Bahkan ibadah, pengabdian, atau kewajiban-kewajiban agama yang dilakukan dengan dasar syukur, sebagai lawan dari kufr, akan jauh lebih berkualitas ketimbang jika kewajiban-kewajiban itu dilakukan untuki memenuhi perintah Tuhan semata, ataukah hanya mencari pahala atau menjauhi siksaan. Dengan titik tolak syukur, kewajiban-kewajiban itu akan dilakukan oleh seorang hamba dengan penuh keikhlasan untuk membalas kebaikan-kebaikan Tuhannya, meskipun hal tersebut tidak akan pernah memadai. Sementara pembangkangan terhadap perintahperintah Tuhan, pelanggaran terhadap larangan-Nya, penyalahgunaan 
nikmat-Nya pada hal-hal yang tidak semestinya, jelas merupakan kealfaan membalas kebaikan-kebaikan Tuhan yang berarti kekafiran terhadap pemberian nikmat itu (Cawidu, 1991:150).

Hadis tersebut sejalan dengan pengertian $k u f r$ dalam Alquran yang salah satu pengertiannya adalah lawan syukur.

\section{Membunuh Sesama Muslim}

Dalam matan hadis (sebagaimana dikutip sebelumnya)

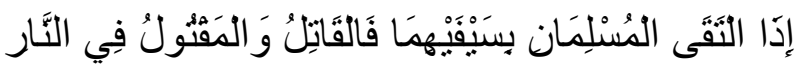

Terjemahnya:

Apabila dua pedang muslim bertemu, maka yang membunuh dan yang dibunuh masuk ke dalam neraka.

Dalam hadis di atas, secara tekstual hadis, tidak ditemukan sama sekali perkataan kufr. Hadis tersebut hanya dipahami sebagai larangan sesama muslim untuk saling membunuh sebab yang melakukannya akan dimasukkan ke dalam neraka.

Begitu pula, dari hadis yang ditampilkan dengan subtema yang sama, tidak ditemukan redaksi yang berbeda secara mendasar, bahkan hampir seluruhnya memiliki lafal yang sama, kalau pun ada yang beda tetap memiliki makna yang sama.

Namun secara kontekstual, hadis di atas dapat dihubungkan dan memiliki keterkaitan dengan makna kufr dalam pengertian melakukan perbuatan dosa besar sebab hampir semua perbuatan yang mengakibatkan orang dimasukkan ke dalam neraka adalah dosa besar. Menurut Ibn 'Abbâs, semua perbuatan dosa yang diancam Tuhan dengan siksa neraka, kemurkaan dan laknat-Nya tergolong dosa besar. Begitu pula menurut Al-Ghazâlî sebagaimana yang dikutip oleh Harifuddin Cawidu, bahwa setiap perbuatan yang dilakukan dengan tanpa perasaan takut, tanpa rasa penyesalan, dan bahkan disertai sikap menganggap enteng, maka perbuatan tersebut termasuk kategori dosa besar (Cawidu, 1991:11).

Selain argumen di atas, ditemukan pula hadis lain sebagai pendukung pendapat di atas yaitu: 
قال النبى (ص) من قتل معاهدالم يرح رائحة الجنة وان ريحها توجد من مسيرة

اربعين عاما

Terjemahnya:

Barang siapa yang membunuh orang terikat dengan perjanjian setia dengam kaum muslimin, maka ia tidak akan merasakan baunya surga dan sesungguhnya baunya surga telah didapatkan dari jarak tempuh empat puluh tahun lamanya (H.R Bukhârî).

Dari hadis di atas, dapat dipahami kalau membunuh non muslim (Ahl al-Zimmî) dapat menjauhkan seseorang dari mencium bau surga apalagi membunuh sesama muslim (Q.S Al-Nisâ' (4):9)

Dari uraian-uraian sub-sub tema hadis tentang $k u f r$ dapatlah dipahami bahwa makna $k u f r$ dalam redaksi hadis-hadis atau yang diduga memiliki makna yang sejenis, tidaklah dapat dipahami sebagai makna $k u f r$ dalam pengertian pengingkaran atau pendustaan terhadap Tuhan, Rasul-rasul-Nya sebagai antipoda dari iman, tetapi memiliki atau mengandung arti serta diduga sebagai dosa besar.

\section{PENUTUP}

$K u f r$ dari segi bahasa mengandung arti menutupi malam atau menutupi siang atau benda-benda dengan kegelapannya, sedangkan secara istilah, $k u f r$ diartikan sebagai pendustaan terhadap Rasulullah dan ajaran-ajarannya atau merupakan antitesa dari iman. Yang menjadi landasan pengertian $k u f r$ dalam studi ini adalah $k u f r$ dari segi bahasa.

Melalui metologi takhrîj dan shyarh al-hadith bi al-maudî'î, maka ditemukan konsep/makna kufr yang terdapat dalam matan-matan hadis antara lain, hadis-hadis tentang meninggalkan salat dengan sengaja, melupakan nikmat Tuhan sebagai lawan dari syukur serta membunuh sesama muslim termasuk hadis berkualitas shahih.

Hadis-hadis tentang $k u f r$ memberikan pemahaman bahwa makna $k u f r$ dalam tiga sub tema tersebut tidak dapat dipahami sebagai $k u f r$ lawan dari iman tetapi dosa besar.

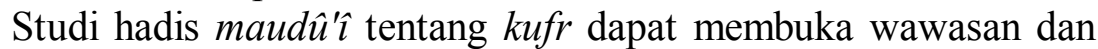
pengertian kita tentang makna kufr yang sesungguhnya dari berbagai redaksi/lafal hadis. Hal ini dimaksudkan agar tercipta suasana rukun dan damai baik secara internal di kalangan masyarakat muslim 
maupun secara eksternal dengan pemeluk agama lain, dalam arti tidak saling menuding kafir bila kita tidak sejalan atau sepaham dengan orang lain, apalagi dalam masyarakat yang serba plural.

\section{DAFTAR PUSTAKA}

Amin, Muhammadiyah. 2004. Menembus Lailatul Qadr: Perdebatan Interpretasi Tekstual dan Kontekstual. Makassar: Melawi Press.

al-Asfahânî, al-Raqîb. t.th. Al-Mufradât fî Ghârib al-Qur'ân. Edisi MS Kailani. Mesir: Must $\square$ afâ al-Bâbî al-Halabî.

al-Bâqî, Muhammad. Fuâd 'Abd. 1981. Al-Mu'jam al-Mufahras li al-Fâz alQu'rân al-Karîm. Beirut: Dâr al-Fikr.

al-Bukhâri, Abû al-Mughîrah ibn al-Bardizbât. t.th. Sahîh Bukhârî. Jilid 4. Mesir: Dâr al-'Ilm.

Cawidu, Harifuddin. 1991. Konsep Kufr dalam Alquran: Suatu Kajian Teologis dengan Pendekatan Tafsir Tematik. Jakarta: Bulan Bintang.

Ismail, M. Syuhudi. 1995. Kaidah Kesahihan Sanad Hadis: Telaah Kritis dan Tinjauan dengan Pendekatan Ilmu Syariah. Cet. ke-2. Jakarta: Bulan Bintang.

Nasution, Harun. 1979. Islam Ditinjau dari Berbagai Aspeknya. Jakarta: UI Press.

Rahman, Fazlur. 1987. Islam. Diterjemahkan oleh Senoajdi Saleh Cet. ke-1. Jakarta: PT. Bina Aksara.

Saltût, Mahmûd. Islâm, Aqîdah wa al-Sarî'ah. Kairo. Dâr al-Qalâm.

Wen Sick, Arnold John. 1981. Miftâh Kunîz al-Sunnah. Terjemahan ke bahasa Arab oleh Muh $\square$ ammad Fuâd 'Abd al-Bâqî. Lahore t.p.

Zakariya, Ahmad bin Farîz. 1994. Mu'jam Maqâyyis al-Lughah. Beirut : Dâr al-Fikr. 